Title page

Title: Anticipating the apocalypse: Monstrous educational futures

Author's name: Esther Priyadharshini

Affiliation: Senior Lecturer, School of Education \& Lifelong Learning, University of East Anglia (UEA).

Declaration of Interest: None

Address: School of Education \& Lifelong Learning, University of East Anglia (UEA), Norwich, NR4 7TJ, UK.

Email: e.priya@uea.ac.uk

Corresponding author: Same as above. 


\title{
Anticipating the apocalypse: Monstrous educational futures
}

Educators have been called to engage with the ontological problematic of the 'future' - its not-knowable nature - and to consider the radical implications of this notion for education. However, orthodoxies of schooling, research and institutional logics can work to constrain the space and tone of futures talk. One way of expanding the scope of such talk is to engage with the radical potentialities of futures by making space for youth preoccupations and speculations that exceed realist notions of how to anticipate futures and prepare for them. This paper explores how functions of the 'speculative' and 'monstrous', as elaborated in literary and popular culture analysis find echoes in data gathered with youth about their visions of 'fantastic' futures. These fantastic/monstrous narratives reveal the salience of dystopian/apocalyptic visions for youth and the different functions they can fulfil. These encounters also expose challenges for education and research that must be met if they are to remain relevant to young peoples' needs to imagine, anticipate and prepare for monstrous futures.

\section{Key words: Youth futures; speculative/fantastic; dystopia, apocalypse}

\begin{abstract}
A future that would not be monstrous would not be a future; it would already be a predictable, calculable, and programmable tomorrow (Derrida, 1995, 387).
\end{abstract}

The connection that Derrida makes between 'the monstrous' and 'the future' plays an important part in the arguments this paper tries to advance. Although Derrida is referring to a monstrous newness that will shake-up the normalcy of theory and philosophical thought, the idea that the future must be anticipated as 
monstrous feels appropriate in the context of a paper that engages with the speculative, dystopian elements of futures that young people can envisage. The starting point for this paper is that the nature of talk about 'the future' within educational/institutional spaces can be severely constrained by certain 'anticipatory regimes' in education (Amsler \& Facer, 2017). Conversations with youth can be circumscribed by what appears on the immediate horizon and practices confined to pragmatic and programmable decisions about the tomorrow. When the telos of education is interpreted as improving academic grades and employability, conversations with young people can be confined to exhortations to aspire better/greater, to maximize grades, improve employability skills, choose appropriate subjects and get employment ready. Futures talk is thus often conducted in a distinctive aspirational, yet pragmatic register where the emphasis is on being 'realistic', and on focusing on tangible actions and programmes.

These anticipatory regimes are inevitably shaped by a combination of pressures and agendas that bear down on schools, through school inspections, policies, statutory regulations, guidance documents, etc. For instance, in the UK, recent government documents on policy and guidance for school careers advisers ${ }^{1}$ (DfE 2018a, 2018b, 2018c) illustrate a discourse that presents futures as

\footnotetext{
${ }_{1}^{1}$ These documents set out how schools are expected to provide such advice and processes of monitoring of such provision. Among the many features of this initiative are a set of 8 benchmarks that schools are expected to meet by the end of 2020 (2018a, p. 5). The rationale for this approach is purportedly to improve previous provision that did not explicitly link the pathways from schooling to future jobs and careers.
} 
programmable and driven through organisational logics, rational choice and individual effort:

There is a significant mismatch between the careers that young people want to pursue and the opportunities available. Labour market information (LMI) can help young people and their parents/carers to understand the salaries and promotion opportunities for different jobs, and the volume and location of vacancies across different sectors. Schools should make sure that, by the age of 14, all pupils have accessed and used information about career paths and the labour market to inform their decisions on study options. Schools should explain the value of finding out about the labour market and support young people and their parents/carers to access and understand this information (DfE 2018a, p.18).

Such directives recognise the role of the structural features of the economy - the labour market in this instance - that can shape future lives. They note the gap between want and opportunity, i.e. the gap between what young people might desire and the opportunities available. However, this acknowledgement of structural elements is framed, not as a constraint, a problem of limited opportunities, but as a problem of inappropriate or unrealistic desire/ambition/aspiration. Far from raising aspirations, such moves are open about the importance of managing desires. They illustrate the institutional and policy climate with regard to young peoples' futures and how they are framed. Attempts at managing - "cooling out" - the gap between culturally encouraged aspiration and institutionally provided means of achievement are not new either (Clarke, 1960, cf. Goffman 1952). The ideal student-citizen in the making has long been encouraged to be pragmatic, even compliant, by seeking to shape 
themselves to fit the spaces offered by the labour market; a rational subject, able to 'choose' their future by suppressing some kinds of desires and focusing on others. This requires teachers, pupils and parents too, to exercise their 'choice biographies' (Beck 1992), but one where the object of choice is already marked by desirable/undesirable, appropriate/inappropriate, qualities. Such orientations also tend to present industry/work conditions as deterministic and larger than the potential agency of individuals with transformative ideas.

Focusing on the labour market and employer needs as an organising factor is a pragmatic response but one which also requires a reshaping of young peoples' desires and fears. Similar tendencies have been critically analysed as a process of 'infantalising' desires (Aoki 2005) through standardisations that squeeze out the singular student as much as the singular teacher (Wallin, 2014).

The study on which this paper is based was therefore an attempt to broaden the scope of futures talk beyond institutional preoccupations, to seek out young people's perspectives on futures that may not be readily recognised or valued in the everyday practice of schooling. The first phase of the study focused on young peoples' interests, their favourite leisure activities and cultural sources, solicited through questionnaires. The second phase requested volunteers to engage with a range of activities, spread over two separate encounters across a year. The material for this paper is drawn for this subset of data from the second phase, from 6 volunteers (anonymised through pseudonyms) aged between 1517 years over the course of fieldwork. Imagining and articulating futures is not without its challenges. Firstly, asking young people to share their dreams and anxieties has an invasive quality (Lyon \& Carabelli, 2016). Hence it was important that those who volunteered did so without feeling coerced and felt able to withdraw at any time. They were reminded of this at each visit and although there were no withdrawals, the numbers remained small. Secondly, 
young people can feel constrained by institutional or adult signals about the 'right' or 'appropriate' answers/desires. Demands to talk about futures can be experienced as 'paralysing' by young people (Bateman 2014) particularly in institutional spaces which exude an expectation of realism i.e., of reasonable predictability and plausibility. Changing this climate requires adults to depart from established roles of directing or guiding young people from a position of knowledge and authority. Such research also needs to consciously move away from the predictive intent of forecasting to the exploration of multiple, disparate, even unbelievable possibilities. It requires honing an attitude of attending to the emergent without needing to be its master (Pink \& Salazar, 2017). These are challenging expectations of researchers that upset established institutional norms of adult-child/youth relationships.

Being conscious of the problem of adults' views of the future overdetermining young people's futures talk (Bateman 2014) there was a concerted effort in this study, to create an environment where participants would feel able to articulate any issues of import to them, including contrafactual futures, i.e. futures not easily imaginable by adults, and even those that might 'distort, confound or transcend those of adults' (Gough 1990, 308). A range of affective and anticipatory methods (Sardar, 2013) including activities and work-shop style techniques (scenario construction; photo elicitations; speculative timelines; word associations; idea generation, etc.) were put to use alongside interviewconversations and group discussions. No school teachers or authority figures were present during the activities. By encouraging young people to set the terms of the conversation, starting from their favourite youth culture related engagements (sport, books, music, movies, tv series, games), there was a deliberate attempt to start at a place that young people relished. The (volunteer) participants who seemed initially bemused by the opportunity to speculate 
freely, noted how such topics and activities were a rare occurrence. There was no discernible discomfort or distress from any participant and in many cases, the opposite - gratification at being taken seriously - was evident.

A separate challenge is that of unpacking and interpreting words and experiences without 'flattening' them into pre-existing frameworks. Researchers who use a mix of traditional and innovative methods with young people still wrestle with the unresolved challenges of analysis (Invinson \& Rennold 2013; Lyon \& Carabelli 2016). In this study, the analysis focused on futures talk that exceeded institutional frames of intelligibility, or how these futures narratives departed from the mainstream narratives of futures talk within schooling. It was less concerned about the source/influence behind their orientations to the future - almost all were drawn from mainstream popular culture's array of outputs. In the event, the discussions surrounding the activities rarely if ever touched on typical institutional discourses related to grades or jobs/careers. These analytic aims were guided by discussions about the status of data and the practices of interpretation and analysis in educational research, particularly the efforts to reinvent qualitative research following various 'turns' in social theory speculative, affective, ontological, posthuman, etc. (MacLure 2015; 2017). One of the challenges is to go beyond the pattern-detecting, representativenessseeking, coding and categorising processes that are often about the mastery of the researcher, and her ability to control data and its explosion of meanings, and of difference itself, into manageable themes. The relationship with data is hence re-oriented to pay attention to moments of wonder, curiosity, horror or other pleasant or uncomfortable affect, those moments when data (and participants) exceed the frames offered by research convention (MacLure 2013a, 2013b). 
For example, in this study, participant data was not subject to examination to detect what may lie 'under' or 'beyond' the surface of what was conveyed, particularly so when the data was about futures that are not normally at home in institutional discourses, and therefore a form of critique in itself. It is important to clarify that this is not about eliciting and valuing only the unconventional in participants (which would be an unbearable burden on subjects) but more about opening up the conventions of research to experimentation. Here it meant that theories and ideas that best resonated with participant conceptions of the future were sought. For instance, discussions on 'the speculative', 'dystopia' or 'horror' span many subject disciplines, genres and orientations, but the ones picked to build the argument of this paper are drawn from popular culture and literary commentary - genres that repeatedly surfaced in young people's talk. This also allowed a consideration of moments when the participant narratives diverged from such commentary and analysis.

\section{Speculative narratives in literary and popular culture}

As part of what is typically marginalised in educational contexts are young peoples' articulations about and anticipations of dystopian or 'fantastic' futures even as its salience becomes apparent under the right conditions, as in Springgay and Truman's (2019) research in schools. In contrast to institutional programmes, popular culture for young people inhabits darker worlds, reveling in the pleasures and potential of speculative and dramatic anticipations. As the material in this paper will show, these dystopian visions arise from broader concerns about their and their world's problems. They were pieced together from exposure to news programmes and documentaries, emergent information and knowledges, and were particularly attuned to mainstream, popular culture outputs. Young adult genres across the mediums of literature, movies, gaming 
or tele-series, evidence a large compendium of globally successful fantasy narratives, with most highlighting the centrality of dystopia/horror to young audiences. A chief characteristic of speculative narratives is their break from more realist styles, as the host of sub-genres they encompass indicate - horror, gothic, supernatural, fairy tales, magic realism, sci-fi, cli-fi, dystopia. Cultural commentators have noted that the break from the more realist genres makes room for inventive aspects (Michael, 2018) that allows an interrogation of what it means to be human, humane and to engage with post-humanism (Bradley, 2017 ) in a way that reflects shifting global concerns. Central to this aesthetic is a recognition that developments in the world and in human experience are 'novel', in the sense that they have never been known before in human time/memory for instance, the rapid reach and embedding of techno-capitalism, the rate of species extinction, or the ferocity of a range of climate change phenomena are all 'new' challenges to which no prior experience speaks. At this juncture, a focus on the inner lives and travails of individuals, or the reliance on known, familiar or mundane contexts - matters that constitute what has been hitherto presented as 'the real' - is no longer felt to be sufficient. Speculative narratives by contrast allow a freedom to consider rapidly changing contexts, unprecedented events and improbable occurrences in a dramatic manner that realist narratives that are wedded to the ordinary, to probabilistic patterns, and the predictable, cannot. They are believed to facilitate an analysis of the world in a way not usually analysed, often by triggering a form of 'cognitive estrangement' (Suvin, 1979), to re-view the world, think afresh, and thus to envision and instigate new kinds of action. Elements of the surreal, unreal or improbable, are seen as crucial in helping break the modernist habit of fetishising "the real". In turn, the real itself begins to be revealed as a careful construction that works hard to conceal occurrences deemed too weird or too unbelievable to be accommodated - as revealed by the commonly heard 
phrases "if this were in a novel, no one would believe it" (Ghosh, 2016, 24), or "truth is stranger than fiction" or "you couldn't make it up". To make things up then, is to make them up in a particular realist register that makes them intelligible.

If the telos of education is to be much more than pragmatic, then engaging with the entanglement of the present to matters far beyond the apparent-real is crucial. In the next sections, this paper looks at speculative narratives of young participants to consider different functions/roles they play and to illustrate the importance of engaging with the 'monstrous' in imagination.

\section{Unfathomable futures}

One of the striking features of young people's talk about the future was their insistence on the unknowability and uncontrollability of futures. Mostly, the 'unknowability' related to its potential for evolution, its amalgam of disparate elements, events and factors that it troubles the idea of a predictable pathway from the present. At other points, there was an awareness of the future as unknowable because it encompassed distant temporalities (on a geological or evolutionary time scale) and unusual futures that were beyond current comprehensions.

Phil was most articulate about his belief that a dystopian future of some kind awaited the world. He stated that the likelihood of some kind of apocalypse/dystopian future affecting his generation was as high as "8 in 10... because there are SO many different things that can lead to an apocalypse that it will definitely happen..." He listed possibilities of a viral outbreak, a mutation of this perhaps leading to a zombie apocalypse (as seen in the key cultural texts of 
his life - 28 Days Later, 28 Weeks Later, The Walking Dead, and World War Z), some ecological accident or disaster leading to a global environmental meltdown or even some catastrophe triggered by war between Russia and the NATO countries. At the same time, Phil hoped that the future might fulfil the promise of space inhabitation so that humans could have an opportunity to do things differently and better.

Jo saw the future as a mix of "good, bad, ugly..., all mixed up", like her favourite television series 'Futurerama', which she described as both "funny and dark". This ambivalence was echoed in Faith's prediction that advances in medicine would gather pace but this could be equally "good or bad". It was clear that the word 'advances' was not used to connote an exclusively positive development, as what appears to be an advance today may well turn out to be disastrous with hindsight. The future was charged with such unpredictability that it would "lack control and direction". These understandings were a qualitatively different approach to the future, revealing both playful and serious sensibilities.

Lana spoke about her desire to fashion her own self. She saw herself as a "workin-progress", and wanted to become more confident, more open, and kinder. But the unknowability and unpredictability, even of one's own future self was central to the conversation. The uncertainty of these predictions and the awareness that the future may have continuities from the present but that it also presented with multiply-forking pathways was a notable theme in all interactions. The future was a different dimension where newness was inevitable and endless possibilities existed. This however, was not a source of horror or fear in itself. In a reversal of dominant narratives about uncertain futures, here there was hope in the possibilities of unpredictability. The fears emerging in young people's talk 
were those triggered by futures that would not be different but would reproduce the monstrosities of the present.

\section{Normal monstrosities}

The most commonly voiced fears were about irreconcilable divisions in society. Faith felt that a possible future would feature "extremism and conflict in human populations and societies". These were not described as wars between countries, but more as divisions within societies. Lana was specific about the kinds of culture wars that could be exacerbated in the future, "...there will be more problems. Like with gay marriage. I'm okay with it now, but some people who I've grown up with, (even) when they're 60, they still won't approve of it. We've not been taught how to deal with this yet..." She imagined a potential scenario like the one illustrated by The Hunger Games series: "... where two sides are not able to talk to each other because values are so different... but this is true even today. People from my rough area will not mix with someone say, from Harrow... not because we don't like each other but because we don't mix... it's really materialistic as well... some have no wealth... or health..." The lack of contact, and of 'mixing', and tolerance between different views could steadily increase, entrenching different values, exacerbating an inability to talk to each other, and thus engender conflict. Stark inequalities were attributed to the growth of these divisions. Max who hoped for a career in health care seemed more attuned to current inequalities in accessing health care. She spoke at length about a documentary she had watched on "appalling mental health services. There was a young girl who had to be separated from her family because there was no provision near where she lived..." If such trends persisted, they would lead to a further "segregation of people" along lines of cultural values, material wealth and health. 
In these dystopias, there would be a loss of common ground, loss of common experience and therefore a loss of relatability between humans. Each picked a current source of horror and feared its presence in the future. These seem to be prime examples of 'normal monstrosities' (Derrida 1990). Derrida suggests that we learn to think of the 'normal' as itself 'monstrous', as an interest in the everyday monstrous can disturb and potentially transform the norm. In so many of the young people's discussions, there was an engagement with the normal's capacity to be monstrous, and a sense of horror that the (radical, promising) future may not materialise. Taken along with the theme in the preceding section - that hope resided in unknowability and therefore in the potentiality of futures this indicates an acknowledgement of continuities from the present being the most problematic for hopeful futures.

\section{The illusion of everyday security}

In contrast to the horror of normal (already experienced) monstrosities of the present, Phil's vision of the apocalypse focused on the terror to be caused through human in-fighting, when norms governing society fall away in the desperate fight for survival. In the event of an epidemic outbreak of any sort, Phil claimed that his first response would be to flee from other humans: "Cities aren't good because they are more crowded, and there's loads of people who aren't prepared who might die, and even if people survive, they will be fighting over stuff. It would be too dangerous." The notion of proximity to other humans being the greatest threat, is an oft-repeated theme in zombie fiction and Phil drew on this to imagine his actions and decisions: "If there was a flu pandemic for example... I would not go anywhere near a city. Just get out...." 
This is an exposure of the fragility of organised 'civil' society under extreme conditions. In the context of popular culture, the monstrous/horror arises as a result of a moment of epiphany, a moment of insight and therefore seen an epistemological good in itself. For instance, Nickel (2010) surmises that horror is experienced when the security of the familiar/real' is exposed as a false construction. Horror in this formulation, affords the reader/viewer a unfamiliar perspective on 'common-sense'. Using the example of the inexplicable attacking birds in Hitchcock's 'The Birds', he claims: "it helps us to see that a notion of everyday life completely secure against threats cannot be possible, and that the security of common sense is a persistent illusion. ...The idea of security in the everyday is based on an intellectually dubious but pragmatically attractive construction" $(2010,17)$. He argues that such experiences of horror can produce new but unsettling understandings of how the world works. Horror exposes the construction of everyday security and our reliance on it, and offers in its place, a more insightful, if terrifying, understanding.

Taking this further, the literary critic Todorov (1975), observed that the 'fantastic' is that which unsettles, because it is typically triggered when a protagonist experiences an event which cannot be explained by the laws of the familiar world. It is a duration of uncertainty, a period when one is suspended between two equally uncertain states - either one does not know the world (anymore) or one does not know oneself. It evokes a dizzying moment, a 'wavering' between "two abysses, neither of which are comforting or particularly reassuring" (Thacker 2015,6 ). Both possibilities in that moment of the fantastic, are equally plausible and implausible, and neither can be accepted or rejected. Such impossible choices can even drive some to the point of (apparent) insanity (Catlett, 2017). This is a vertiginous moment of not-knowing, an epistemological 
uncertainty that triggers horror. So an epistemological good (in the moment of insight) can lead to horrific uncertainty, indicating the shifts between different affective experiences and cascading levels of horror. Echoes of such horrors from insight and uncertainty emerged in some unexpected places in the young peoples' narratives, most notably in their growing sense of disappointment with inter-generational relations.

In Phil's apocalypse, a striking feature is the reversal of roles normally assigned to young people and adults. Survival narratives tend to be based on 'patriarchal pedagogies of survival', on an ethos premised on claiming and fortifying territory, fending off (un)human others, hoarding resources and securing reproductive labour (Trimble 2012). These dominant apocalyptic narratives focus on the male hero, and often replay undead elements of colonial and exploitative histories. Where they do expose ethical and affective alternatives, these may be signalled through marginal figures of women and children. In Phil's narrative there is a departure from this trope - here, there is a distinct divide between the generations and an obvious suspicion of adults: What about people? Would you stop for family? Or just get the hell out of the city?

I'd take my brother but probably not my mother or father. (Laughing) (Laughing) Why?

Because he's younger, so he will be of more use. And help rebuild society for the future. ... I might take some of my friends. We've agreed that we'll all head towards 'Greenacres' (a wooded area near a large body of water outside the city, but within walking distance of his school) and then we'll meet and then decide what to do. 
As it turned out, Phil was not being callous or cold-hearted in choosing to leave behind his parents. His long-running efforts to get them to engage with his vision of possible apocalyptic futures had not gained ground, leading to mutual frustration, and he did not think that he would ever gain their confidence or convince them. With their attachments to pre-established orientations to the world, their habits and patterns of thinking and behaviour, they would only get in the way of survival. Phil seemed convinced that trying to proselytize an inattentive, unyielding audience was not for him: I don't think it's worth convincing them...

When asked how he would be able to relate to other people at a time of heightened paranoia, panic and distrust, his answers foregrounded his sense of solidarity with other young people:

How will you know if a stranger is safe or trustworthy?

If they seem in need, I'd help them. If they're children, they're probably going to be good people. The best thing is to just ask them if they've been bitten. Then maybe keep them near but not with the group. Keep an eye on them and you'd know how long before the virus turns them into zombies...

Perhaps some may read Phil's instinct to trust most children and mistrust most adults, as naïve. But it is clear that his frustration with adult notions of the future (and thus of how to prepare for it) yielding no quarter to youth projections is what drives his vision. This critique of intergenerational relations finds echoes in other participants too:

"We talked about Brexit amongst ourselves a lot. We thought we should been allowed to vote. ... The older generations voted 'Leave'. If we'd been able to vote it would have looked very different..." 
This was an emergent critique of the older order and also of unequal intergenerational relations. There was a sense of youth concerns going unheard or treated as less important, and a lack of respectful reciprocity between generations. It is not hard to draw the link between the horror of social breakdown in the future and their perception of already being marginalised as non-participants in the present. Here was a horror from knowing, through epiphanic moments (Brexit) as well as through a gradual insight into the illusion of adults as a source of security either now or in the future. Adults, through their responses and actions are visibly involved in securing futures, but these may be insecure futures from young peoples' perspectives².

\section{Agency in the face of senselessness}

The realm of the fantastic is seen as facilitating new understandings about acting in the midst of uncertainty: in the speculative genres, characters are confounded and horrified when confronted by something unfamiliar, unknown, drawn from an alien sphere. Beyond the pain, disappointments or spectacles of violence, the world at large, with its myriad networks of non-human actors, materials, events and assemblages, presents as mostly indifferent to the human predicament (Fahy 2010). The genre can render humans humbled and decentred. And yet, these narratives grip readers/viewers because the protagonists (and by extension, the viewer/reader) must carry on, even after recognising this indifference and the absence of perfect knowledge or certainty: they must continue to act in the presence of fear (Nickel 2010), brutality and senselessness.

\footnotetext{
2 The study was conducted before the start of the global school climate strikes which express similar resentments and frustrations much more explicitly.
} 
Phil's plan for how he would navigate an apocalyptic world, where taken for granted systems of security and stability had broken down, was well-thought out. A list of possible actions were ranked by priority and he had already trained and prepared for many eventualities. His plan was to leave the city with his friends, taking with him dried and canned food. On arriving at the outskirts, the priority would be to secure safe drinking water. Water needs to be filtered, boiled and disinfected ...I've got water filtration equipment and tablets for disinfecting. I have this with me all the time. ...I've practiced filtering water... and making fires in my back garden.

There would be regular food inventory checks, and careful rationing. ...We'd also hunt, so try and mix it up, so the food can last longer. Phil's reference to hunting, was a serious one. His post-exam summer plan included archery lessons, as part of his work towards a Duke of Edinburgh award $^{3}$. In doing this, he aimed to satisfy both his ambitions to survive the apocalypse and the more normative ambitions of parents and teachers to improve his Curriculum Vitae. The development of his curriculum vitae - rather literally, his 'life course' - was part of his survival project extending from the mundane everyday into fantastic realms and unusual temporalities.

When participants were asked to identify how schools could equip them meet the range of anticipated futures, amongst the list were requests for developing critical literacy skills to assess news media reports from a variety of sources, discussions of party political manifestos and promises made before elections

${ }^{3}$ Duke of Edinburgh award -a youth achievement award that promotes a range of skills and activities for young people and also hopes to enhance CVs and employability profiles. https://www. dofe.org/about-us-2/ 
and referendums (even if they were not yet allowed to vote), preparedness classes for a range of scenarios such as power outages, outdoor survival skills, subsistence skills, and tips to cope with future student debt. This is a pragmatic list but one stemming from speculative visions of the future, that aims to retain a sense of agency in the most dystopian of futures.

\section{Contagious pleasures}

It also became clear that the negativity of the monstrous in young people's narratives was entangled with more positive affect. Perhaps the most appealing function of fantastic genres are the immediate pleasures and intense affective, bodily experiences they offer - racing pulses, sweaty palms, dry mouths, the inability to look away or to scream. Fahy (2010) concludes that such affective experiences are tolerable, even pleasurable, because the genre allows us to encounter the dangerous and horrific in a safe context - when the book/movie ends, there is a feeling of relief and control regained. Still, it is the nonreal/surreal nature of speculative genres that allows us to question, analyse and evision alternatives in ways that would not otherwise be possible.

In this study, apart from functioning as an important outlet to express young people's worst fears and anxieties, dystopian visions of the future were tied up with exciting and hopeful possibilities. In fact, hope resided in the possibility that dystopian futures may allow an undoing of the normal monstrosities of the present. Most strikingly, the dystopian future was often a joyful and thrilling device, an exercise in imagination, an opportunity to devise ingenious solutions to the problems of the present, and a preparation for uncertain and therefore unexpectedly hopeful futures. 
As apparent in the following exchange, the exhilaration of the monstrous - in this case, imagining surviving a zombie apocalypse - can also be contagious to attuned listeners. In the following conversation, the contagion of the exhilaration of horror infects both speaker and listener:

Ok, so you have the basics - water, food, fire and shelter. What about medicines? What if someone had some chronic condition, like they needed inhalers for asthma?

Yeah. I'm asthmatic anyway.

So you will need your inhalers? Let me guess - you'll take as much as you can when you leave the city. How? Raid a pharmacy? Yes, there's two near me anyway. I'd probably head to one near my dad's because if I do, I can also pick up my bike. Better than a car, less noisy, and will attract less attention ... [The queues and quarrels over fuel, rehearsed in several apocalyptic films/tele-series ensured the need for no further explanation].

So get the bike, go to pharmacy, and... raid it? What will you take? Some antibiotics, inhalers, some paracetamol.

...So you've got knives, water disinfectants and filters, medicines, blunt instruments... (Laughing)... What don't you have?

Guns and flares.

I can see the use of guns, but why would you need a flare?

To distract, to communicate or to kill a zombie. You can kill if you shoot it in the eye....

...And what if there was say, some biological warfare? Do you have gas masks? No, mum won't let me get it. But I do know how to make a gas mask.

Phil then explained how he could assemble a make-shift gas mask with a water bottle, a sock and some charcoal. He was aware of its limitations but claimed it was more important to always act to survive with whatever resources were at hand. 
The affective thrills of such moments are noticeable in other cultural outputs, especially musical genres like Jungle (Fisher 2014, 31) or Detroit techno music (Pope 2011) which similarly arise out of despair and frustration but offer a similar 'jouissance'. Fisher $(2014,31)$, has written of the 'lure of the dark' of Jungle music as "a libidinsation of anxiety itself, a transformation of flight and fight impulses into enjoyment. ...At a certain point, the unrelieved negativity of the dystopian drive trips over into a perversely utopian gesture, and annihilation becomes the condition of the radically new". Young adult dystopian or apocalyptic genres are similarly hugely appealing because they too allow the imagining of another world in which betrayal and disenfranchisement through systems of adult authority are exposed, and can be dismantled for more desirable futures (BBC R4, Open Book, 31/12/17). This hopeful purpose of the monstrous is thus also present in young people's visions of the apocalyptic and monstrous futures.

\section{Fantastic futures}

The preceding sections have attempted to illustrate at least four different functions of the monstrous/fantastic in young peoples' narratives of the future a means of engaging with everyday monstrosities; a way of acknowledging the illusion of security; a prompt to act with agency in the face of meaninglessness; and as a device to experience the thrills and contagious hopefulness of surviving the worst of futures. Dystopian narratives which incorporate all manner of affect deserve to be explored as an 'index' of public cultures and social systems (Cvetkovich 2003) particularly in relation to young people's cultures as they intersect with schooling. These are not necessarily asocial, autonomous or random affect (Ahmed 2014; Hemmings 2005) and the question of what they do 
for comprehending and shaping futures - how they compel, provoke, move, inform or inspire them - is important for educators to understand.

The analysis in this paper has proceeded by listening to speculative narratives and juxtaposing them to scholarly work in literary and popular culture studies on dystopian genres. Young people did not simply regurgitate mainstream narratives but also reversed some traditional tropes, making their presence felt, and suggested ways of acting and preparing for difficult futures that are currently ignored within the curriculum. Making more space for youth perspectives on the speculative and the monstrous is suggested as one way of expanding the scope of futures talk as well as that of education itself. These moves can open possibilities for education that steer it away from needing to 'know' or control the future, to sustaining ways of living and acting 'with notknowing the future' (Miller 2001, p.1). Rather than conceptualising education as protection against fearful futures (Facer 2016, 53), the paper offers the suggestion that engaging with speculative fears and hopes may help position both education and young people as more relevant to each other.

In this study, making space for such speculative visions revealed the wide global, social, political and environmental scope of young people's concerns. They therefore suggest a revisiting adult apprehensions about such encounters or topics with youth. There is a suspicion that delving into less than utopian conceptions of the future could lift the lid on despair and despondency, rendering young people even more vulnerable, and that adult responsibilities dictate that their role is to erase or alleviate negative affect and encourage hopeful ones. There is also the danger of anticipating dystopias fed from capitalist mainstream culture that can "bring into being our own destruction: making real the dark images of the future" (Coleman \& Tutton, 2017: 442). These 
are important concerns. However, the encounters with young people in this study reveal that the affects of dystopia do not work in predictable ways - they seem to indicate that hope and despair are not clearly separable in the monstrous, and that there is something to be gained from knowingly engaging with such visions of the future.

The place of speculation and the fantastic is important not only because they can strengthen creative responses to emerging challenges but also because they attend to the full range of young people's preoccupations, desires and fears. But such an approach cannot be based on an assumption that youth, by their youthfulness, somehow are at the cutting edge of a new world, because youth desires are diverse and can also be conservative. The exchanges were a reminder of how, despite the steady rise in the discourse of child/youth participation and their rights to be involved in decisions about their lives, adult concerns continue to shape futures talk. Indeed, the accusation that very figure of a child/young person can come to embody adult desires for the future fuelled by adult utopian fantasy and nostalgia (Bruhm \& Hurley, 2004, xiii) still feels relevant. This requires engaging unconditionally with whatever moves young people and to allow ourselves to be moved by these engagements. In this respect, perhaps it is not just the ontology of 'the future' that is in question but that of education and research too.

\section{References}

Ahmed, S. (2014) The Cultural Politics of Emotion, $2^{\text {nd }}$ Edition. Edinburgh University Press.

Amsler, S. \& Facer, K. (2017). Contesting anticipatory regimes in education: exploring alternative educational orientations to the future, Futures, 94, 6-14. 
Aoki, T. (2005) Curriculum in a new key: The collected works of Ted T. Aoki, Ed. W.F. Pinar and R.L. Irwin. Mahwah, NJ: Lawrence Erlbaum Associates. Bateman, D., 2014. Untangling teachers' images of their futures through their responses to the futures narratives of children. Journal of Futures Studies,18(3): 41-56.

BBC Radio 4, Open Book: Dystopian Fiction. 31/12/17

Beck, U. (1992). Risk Society: Towards a New Modernity. London: Sage, 1992.

Bradley, J. (2017) 'Writing on the precipice', Sydney Review of Books, 21

February 2017. https://sydneyreviewofbooks.com/writing-on-the-precipiceclimate-change/

Bruhm, S. \& Hurley, N. (2004). Curiouser: On the queerness of children. University of Minneapolis Press: Minneapolis, London.

Catlett, B. (2017) Madness as Prophecy in Dystopia: Shakespeare's Hamlet, Nietzsche's Philosophy, and Heller's Satire of Wartime Insanity, Janus Head, 15:1, 173-225, Clarke, B. (1960). The "Cooling-Out" Function of Higher Education, American Journal of Sociology, May 1960, 65 (6): 569-576.

Coleman, R., \& Tutton, R. (2017) Introduction to Special Issue of Sociological Review on 'Futures in Question: Theories, Methods, Practices', 65:3, 440-447. Cvetkovitch, A. (2003). An Archive of Feelings: Trauma, Sexuality and Lesbian Public Cultures. Durham NC: Duke University Press.

Department for Education (DfE), 2018a. Careers guidance and access for education and training providers: Statutory guidance for governing bodies, school leaders and school staff.

https://assets.publishing.service.gov.uk/government/uploads/system/uploads/att achment data/file/748474/181008 schools statutory guidance final.pdf Department for Education (DfE), 2018b. Careers guidance: Guidance for further education colleges and sixth form colleges. 
https://assets.publishing.service.gov.uk/government/uploads/system/uploads/att achment_data/file/749151/Careers guidance-Guide for_colleges.pdf

Department for Education (DfE), 2018c. Careers strategy: Making the most of everyone's skills and talents.

https://assets. publishing.service.gov.uk/government/uploads/system/uploads/att achment data/file/664319/Careers strategy.pdf

Derrida, J. (1995) Passages - from Traumatism to Promise', trans. Peggy Kamuf, in Points... Interviews, 1974-1994. Ed. Elisabeth Weber. Stanford: Stanford University Press, 372-395.

Derrida, J. (1990). 'Some Statements and Truisms about Neo-logisms, Newisms, Postisms, Parasitisms, and Other Small Seismisms', trans. Anne Tomiche, in The States of 'Theory': History, Art and Critical Discourse, ed. David Carroll. New York: Columbia University Press, 63-95.

Facer, K. (2016). Using the future in education: Creating space for openness, hope and novelty. In H. E. Lees \& N. Noddings (Eds.), The Palgrave International Handbook of Alternative Education (pp. 52- 67). London, England: Palgrave Macmillan.

Fahy, T. (Ed.), (2010). The Philosophy of Horror. Kentucky: The University Press of Kentucky.

Fisher, M., (2014). Ghosts of my life; Writings on Depression, Hauntology and Lost Futures. Winchester, UK \& Washington, USA: Zero Books.

Ghosh, A. 2016. The great derangement: Climate Change and the Unthinkable. Chicago, London: University of Chicago Press.

Goffman, E. (1952). 'Cooling out the Mark: Some aspects of adaptation to failure', Psychiatry, 1952, 15 (4):451-63

Gough, N. (1990). Futures in Australian education: Tacit, token and taken for granted futures. Futures 22, 298-310. 
Hemmings, C. (2006) Invoking Affect: Cultural Theory and the Ontological Turn, Cultural Studies, 19:5, 548-567.

Ivinson, G., \& Renold, E. (2013). Subjectivity, affect and place: Thinking with Deleuze and Guattari's Body without Organs to explore a young girl's becomings in a post-industrial locale. Subjectivity, 6(4), 369-390.

Lyon, D., \& Carabelli, G. (2016). Researching young people's orientations to the future: the methodological challenges of using arts practice. Qualitative Research, 16(4), 430445 .

Michael, R. (2018). Friday essay: How speculative fiction gained literary respectability, The Conversation, Nov 1, 2018. http://theconversation.com/fridayessay-how-speculative-fiction-gained-literary-respectability-102568

MacLure, M. (2013a). The Wonder of Data. Cultural Studies $\leftrightarrow$ Critical Methodologies, 13(4), 228-232.

MacLure, M. (2013b). Researching without representation? Language and materiality in post- qualitative methodology. International Journal of Qualitative Studies in Education. 26(6), pp.658- 667.

Maclure, M. (2015). The 'new materialisms': a thorn in the flesh of critical qualitative inquiry? In: Critical Qualitative Inquiry Foundations and Futures. Left Coast Press.

MacLure, M. (2017). Qualitative methodology and the new materialisms: "A little of Dionysus's blood?". In Denzin, N. K., \& Giardina, M. D. Qualitative Inquiry in Neoliberal Times (pp. 56-66). Routledge.

Miller, R. (2011). Being without existing: The futures community at a turning point? A comment on Jay Ogilvy's "Facing the fold." Foresight, 13(4), 24 - 34 Nickel, P. (2010). "Horror and the Idea of Everyday Life: On Skeptical Threats in Psycho and The Birds. In, Thomas Fahy (Ed). The Philosophy of Horror. Pp. 3341. Kentucky: The University Press of Kentucky.

Pink, S. \& Salazar, J. (2017) Anthropologies and futures: Setting the agenda. In J. Salazar, S. Pink, A. Irving, \& J. Sjoberg, Eds. Anthropologies and futures: 
Researching emerging and uncertain worlds. PP. 3-22. London \& New York: Bloomsbury.

Pope, R. (2011). Hooked on an Affect: Detroit Techno and Dystopian Digital Culture. Journal of Electronic Dance Music Culture, 2:1, 24-44.

Sardar, Z. (2013) Future: All that Matters. UK: Hodder \& Stoughton.

Springgay S., \& Truman, S. (2019) Counterfuturisms and speculative temporalities: walking research-creation in school, International Journal of Qualitative Studies in Education, 32:6, 547-559.

Suvin, D. (1979) Metamorphoses of Science Fiction: On the poetics and history of a literary genre. New Haven: Yale University Press.

Thacker, E. (2015). Tentacles Longer Than Night. (Horror of Philosophy, vol. 3). Winchester, UK: Zero Books.

Todorov, T. (1975). The Fantastic: A Structural Approach to a Literary Genre, trans. Richard Howard (Ithaca: Cornell University Press).

Trimble, S., (2012), Undead Ends: Contested Re-beginnings in Apocalyptic Film and Television, $\mathrm{PhD}$ thesis, McMaster University. Wallin, J. (2014). Education Needs to Get a Grip on Life. 117-139. In, C.Matthew, \& J. Wallin, Deleuze and Guattari, Politics and Education: For a People-Yet-toCome. New York: Bloomsbury Publishing. 